\title{
Bacteriological Quality of Swimming Pools Water in Port Harcourt Metropolis
}

\author{
Smart Enoch Amala, Constancy Prisca Aleru \\ Department of Medical Laboratory Science, Rivers State University of Science \& Technology, \\ Nkpolu-Oroworukwo, Port Harcourt, Nigeria \\ Email: smart.amala@yahoo.com
}

Received 6 November 2015; accepted 4 March 2016; published 7 March 2016

Copyright (C) 2016 by authors and Scientific Research Publishing Inc.

This work is licensed under the Creative Commons Attribution International License (CC BY). http://creativecommons.org/licenses/by/4.0/

(c) (i) Open Access

\begin{abstract}
The bacteriological quality of swimming pool water in Port Harcourt Metropolis was investigated. Ten (10) swimming pools were examined for microbial quality. Out of the 10 swimming pools, 4 (2, 4,7 and 9) had bacterial isolates of $40(100 \%)$. Swimming pools $2,4,7$ and 9 had the bacterial isolates of $10(25 \%), 8(20 \%), 10(25 \%)$ and $12(30 \%)$, respectively. Of the forty (40) bacterial isolates identified, which represented 100 percent, 22 (55\%) were identified as Staphylococcus epidermidis, 10 (25\%) Bacillus cereus, 6 (16\%) Micrococcus and 2 (5\%) Staphylococcus aureus. Among the four swimming pools, 2 and 9 did not have the isolates of Staphylococcus aureus and Micrococcus, respectively. Based on the World Health Organisation (WHO) standard for recreational waters, the absence of coliform and fecal coliform bacteria $(E$. coli) revealed that the ten (10) swimming pools used for this study are considered to be within the acceptable limits for certifying microbiological water quality. However, there is a need for care and continuous maintenance of the swimming pools.
\end{abstract}

\section{Keywords}

Bacteriological, Quality, Swimming Pools, Water

\section{Introduction}

People go swimming in the pools for different reasons, such as for recreational activities, sports or for rehabilitative treatment. In recent years, swimming pools have been increasingly popular and possible maintenance failure might cause public health problems. The latter is because different microorganisms (fungi, viruses, bacteria and protozoa) can be found in swimming pools, which may be introduced into the swimming pool in many ways. 
The risk of illnesses or infections has been linked to faecal contamination of the pool water because of some activities of the bathers, such as passing excreta during swimming. It has been reported that pools may also be contaminated as a result of direct animal contamination, for example, from rodents and birds [1]. The release of faeces by bathers may be inadvertent, in the case of diarrheic stool. Aside from contaminations through the release of faecal materials, non-faecal human shedding (vomit, mucus, skin or saliva) in the pool is potential sources of disease-causing microorganisms [1]-[3]. Bello isolated bacteria such as, Enterococcus faecalis, Clostridium perfringens, Bacillus cereus, Escherichia coli, Pseudomonas aeruginosa, Staphylococcus aureus, Staphylococcus epidermidis and Proteus vulgaris [4]. They reported that the presence of high level of coliform and faecal coliform bacteria E. coli showing that the swimming pools had not met the World Health Organization (WHO) standard for recreational waters. They remarked that swimming pools that did not meet WHO standard for recreational water constitute a serious public health threat, hence, the need for urgent and effective intervention.

The major contaminating bacteria of swimming pools have been reported to be Staphylococci species. Klapes and Vesley, reported that the major contaminants of swimming pools and other recreational waters with high bather density are Staphylococcus epidermidis and Staphylococcus aureus [5]. Allock, noted the potential health hazard associated with Pseudomonas aeruginosa in swimming pool waters, which is frequently isolated from the ears of swimmers with otitis media [6]. Staphylococcus aureus may be present in swimming pool water without the presence of either coliform or faecal coliform bacteria [7]. In addition, Staphylococcus aureus and Staphylococcus epidermides are the major isolated bacteria [8]. More so, there are some bacteria and amoebae, which are free-living aquatic microorganisms. These free-living organisms can also grow in swimming pool water, in heating or air-condition or ventilation system. They can as well grow on other wet surfaces inside these facilities to a point that some of them may cause a variety of dermal, respiratory or central nervous system infections or diseases [1].

Cases of infectious diseases caused by the accidental swallowing of swimming pool water that was contaminated with microorganisms have been reported by some researchers [9]-[11]. According to their reports, some microbes associated with the skin, eye, ear and gastrointestinal tract infection were the most common infectious diseases agents that can be transmitted by recreational waters. This is why the levels of microorganisms in recreational water are important for indexing the health hazard associated with swimming [12]. Alice [13] observed that an outbreak of conjunctivitis in the USA was linked to summer-camping, the chances of contracting the illness increases by 50\% amongst users of the some camp swimming pools as compared to non-users.

This study was carried out to determine the microbiological quality of swimming pools in Port Harcourt, Nigeria, in relation to WHO standard for recreational water; and to isolate and identify the isolated bacteria associated with swimming pools in Port Harcourt and relate them to possible health implications.

\section{Materials and Methods}

\subsection{Study Area}

The study area chosen was Port Harcourt, the capital of Rivers State, Nigeria. Port Harcourt is a metropolitan city with over a million people; it is made up of people from different ethnic groups.

Rivers State is rich in oil and gas, and as a result, a significant number of foreign nationals work in the oil and gas/allied industries, most of which were resident in Port Harcourt. The population of people in the city has increased as well as the social life of the residents. Port Harcourt is a commercial city with sea port and air port, the building of hotels with recreational centres such as swimming pools had been on increase. In fact, most of the hotels and club houses in Port Harcourt have swimming pools for recreational purposes.

\subsection{Description of Pools}

The number of swimming pools used for this study were (10) ten. The (10) ten swimming pools were all located in hotel premises and would subsequently be referred to by their numbers.

Ten (10) swimming pools selected were located in Port Harcourt metropolis and permission was obtained from the authorities to conduct this study. The swimming pools were of varying shapes (e.g. rectangular, circular etc. ) and sizes ranging from $50-1500 \mathrm{~m}$. Their flow through were from 2.2 - $2.85 \mathrm{~m}$ deep and the swimming pools were made of glazed tile. 


\subsection{Collection of Samples}

Each water sample was collected into a sterile $250 \mathrm{ml}$ wide mouth plastic container at depth of about $30 \mathrm{~cm}$ from different regions of each swimming pool. The sampling periods were morning before bath, and evening. The samples were taken to the Microbiology Laboratory, Department of Medical Laboratory Science, Rivers State University of Science and Technology, Port Harcourt, Nigeria; for immediate bacteriological examination.

\subsection{Preparation of Bacterial Media}

Bacteriological media were reconstituted and sterilized according to the manufacturer's instructions. Standard plate count agar, McConkay agar and nutrient agar dehydrated powders were weighed, reconstituted and sterilized by autoclaving at $121^{\circ} \mathrm{C}$ for 15 minutes. They were poured aseptically onto petri-dishes, allowed to solidify and stored in the refrigerator at $4^{\circ} \mathrm{C}$ for subsequent use. All microbiological media used were products of Oxoid, UK.

\subsection{Bacteriological Examination of Samples}

The samples collected were serial diluted and plated by spread plate method using standard plate count agar [14]. Total coliform and faecal coliform counts are estimated on McConkay agar plates [15]. The bacteriological examination was carried out within 2 hours from the time of sample collection and inoculated plates were incubated at $37^{\circ} \mathrm{C}$ for $24-48$ hours.

\subsection{Identification of Isolated Bacteria}

Growth representative of colonies were sub-cultured on nutrient agar medium and incubated for 24 hours at $37^{\circ} \mathrm{C}$. The colonial characteristics on agar plates were taken into consideration. The characterization and identification of isolated bacteria were carried out using the procedures of [16] [17]. The chemical and biochemical tests employed were, Gram's staining reaction, motility, catalase, coagulase, oxidase reaction, urease, citrate utilization and sugar fermentation.

\section{Results}

Out of the ten (10) swimming pools sampled, four (4) had bacterial isolates. The percentage of swimming pools that had bacteria isolates from the ten (10) was 4 (40\%). Out of the four swimming pools, pool (9) had the highest number of bacteria isolated 12 (30\%), while pools (2) and (7) had 10 (25\%) each respectively and pool (4) had 8 (20\%) which was lowest count; as shown in Figure 1.

The results of the frequencies of bacteria isolated from swimming pools as shown in Figure 2, Staphylococcus epidermides was the most frequently occurring bacteria in pools 2, 4 and 9 respectively; whereas Bacillus cereus was the most frequent in pool 7. Bacillus cereus also was predominantly present in the four (4) of the swimming pools that showed bacterial growth. Staphylococcus aureus was the least in frequency occurring in two (2) swimming pools only, while Micrococcus was isolated from 3 swimming pools 2, 4, and 7 respectively, Figure 2.

From the results of percentage occurrences of isolates as shown in Figure 3, Staphylococcus epdermides was 22 (55\%), Bacillus cereus 10 (25\%), Micrococcus 6 (16\%) and Staphylococcus aureus 2 (5\%) respectively. There was no difference in the bacteria types isolated in both sampling periods.

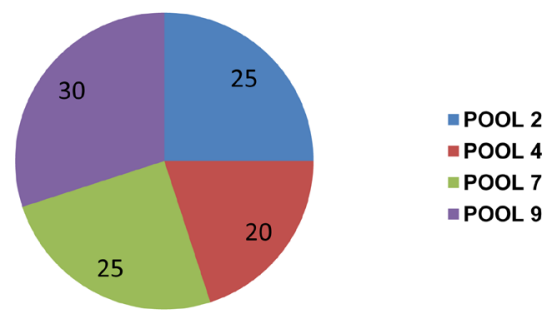

Figure 1. Percentages of total heterotrophic bacterial counts from the four (4) positive swimming pools. 


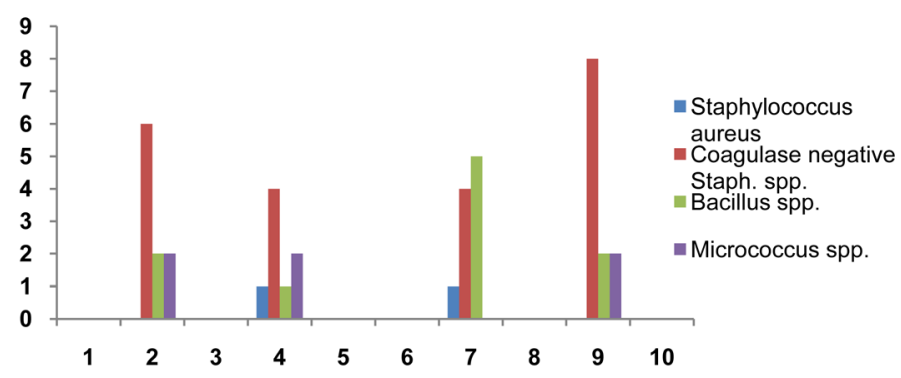

Figure 2. Frequency occurrences of isolated bacteria from each swimming pool.

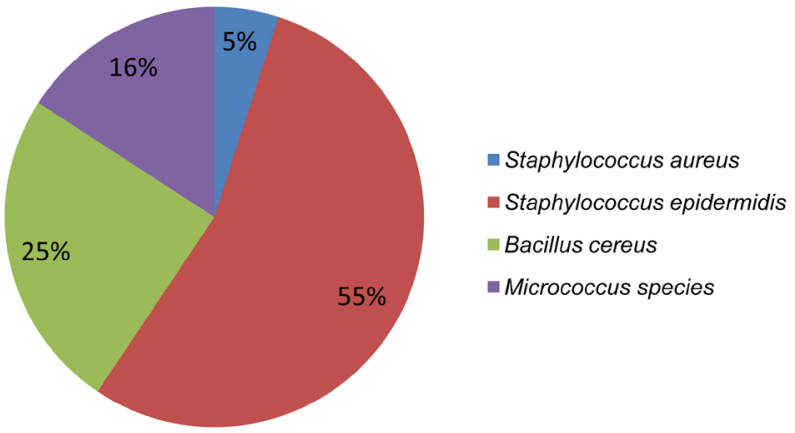

Figure 3. The percentage occurrences of isolated bacteria from swimming pools.

\section{Discussion}

The results of this investigation revealed that four 4 (40\%) out of the ten (10) swimming pools in Port Harcourt used had bacterial isolates. Other workers studying swimming pool bacteriology have isolated various bacteria. Chrissanthy, in Greece, isolated Pseudomonas, Klebsiella, Enterobacter, Staphylococcus aureus, Staphylococcus epidermides and Leuconostoc [18]. In Accra Ghana, George and his colleagues [19] isolated E. coli, Enterobacter faecalis, Klebsiella pneumonae, Staphylococcus aereus and Staphylococcus epidermides. Also, in a related study on swimming pools in Ilorin, Nigeria, Micrococcus, Aeromonas, Pseudomonas, Klebsiella, Lactobacillus, Bacillus, Citrobacter, Corynobacterium, E. coli and Staphylococcus aureus were isolated [20]. A similar study investigating swimming pools in Lagos, Nigeria, the bacteria isolated Enterococcus faecalis, Clostridium perfringes, Bacillus cereus, E. coli, Pseudomonas aeruginosa, Proteus vulgaris, Staphylococcus aureus and Staphylococcus epidermidis [4]. In this study, the bacteria isolated were: Staphylococcus aureus, Staphylococcus epidermidis, Bacillus cereus and Micrococcus. The bacteria that were isolated in both sampling periods were the same. The results are similar to the findings of [8]-[21] reported that approximately $40 \%$ of the microorganisms isolated from swimming pools are species of Bacillus. According to them, the reason is owing to the fact that the species contain spores, which are resistant to disinfectants, for example, percholorine. The results of these findings are not in agreement with our findings because Staphylococcus epidermidis was the most prevalent bacteria isolated.

Staphylococcus aureus and Bacillus cereus could be associated with gastroenteritis when ingested with swimming pool water and both organisms are enterotoxin producers [4]-[22]. Staphylococcus aureus was shown as the most predominant bacteria found to contaminate swimming pool water [8]. This study showed that Staphylococcus epidermidis was the most predominant bacterium. The findings that the species of Staphylococcus epidermidis isolated from the swimming pools is more than other bacterial isolates is not surprising because this organism exist in large number on the human skin. In other words, they are normal flora of the skin. Several years ago, it was reported that coagulase negative Staphylococci species exist on the human skin and do not always cause infectious diseases [5]-[23] but today they have been associated with diverse infections. As the normal flora of the skin, it is frequently isolated from swimming pools. Staphylococcus epidermides can cause severe infections in humans. For instance, Staphylococcus epidermidis, which is coagulase negative and a com- 
mensal of the skin, can cause severe infections in immune-compromised patients. More so, Staphylococcus saprophyticus that is part of the normal vaginal flora is predominantly implicated in genitourinary tract infections in sexually active young women [24]. Even if nowadays owners of swimming pools have provided their pools with a re-circulating system in order to filter and disinfect their pools effectively, relevant research studies show that neither high-tech systems nor disinfectants can prevent the colonization of swimming pool water with hazardous microorganisms [25]-[28].

In this study, the absence of coliform or faecal coliform, such as Escherichia coli shows that some of the swimming pools in Port Harcourt complied to [29] standard for recreational waters. However, the swimming pools in Port Harcourt and other areas in Nigeria as a whole should be adequately and frequently monitored and maintained to ensure they satisfy the recreational needs of the populace. Also, it is important that swimming pool waters should be routinely sanitized and the workers properly trained.

The monitoring for potential microbial hazards (carried out using indicator microorganisms) is necessary in the control of water quality and prevents the transmission of infectious diseases in the swimming pool. The presence of other bacteria could be hazardous to the people who use the pools for example, Pseudomonas aeruginosa associated with otitis media in swimmers [3]-[30].

\section{Conclusions}

The swimming pools examined, met the World Health Organization [29] standard for recreational water of zero coliform and faecal coliform (E. coli). Education of the staff and users of swimming pool will create awareness on proper use to avoid public health hazard.

In addition, there is a call for improving staff training to increase users' knowledge and awareness of the risks.

\section{References}

[1] WHO (2006) Microbial Hazards. In: Guidelines for Safe Recreational Water Environments. Swimming Pools and Similar Environment, Volume 2, WHO Press, Geneva, 26-59 (Chapter 3).

[2] CDC (2001) Prevalence of Parasites in Faecal Material from Chlorinated Swimming Pools—United States. MMWR, 50, $410-412$.

[3] Ezeet, V.C., Onwuakor, C.E. and Ikwuegbu, A.L. (2015) Microbiological and Physicochemical Characteristics of Swimming Pool Water in Owerri, Imo State, Nigeria. Journal of Applied and Environmental Microbiology, 3, 6-10.

[4] Bello, O.O., Mabekoje, O.S., Egberongbe, H.O. and Bello, T.K. (2012) Microbial Qualities of Swimming Pools in Lagos, Nigeria. International Journal of Applied Science and Technology, 2, 89-96.

[5] Klapes, N.A. and Vesley, D. (1986) Rapid Assay for in Situ Identification of Coagulase-Positive Staphylococci Recovered by Membrane Filtration from Swimming Pool Water. Applied and Environmental Microbiology, 52, 589-590.

[6] Alock, S.R. (1977) Acute Otitis Externa in Divers Working in the North Sea. A Microbiological Survey of Seven Saturated Divers. Journal of Hygiene, 18, 359-409.

[7] Mates, A. and Schaffer, M. (1986) A Simple Method for Counting Staphylococcus aureus in Swimming Pool Water. Micriobios, 46, 45-49.

[8] Ita, A.Y. and Ekpombok, M.U. (2004) Pollution Status of Swimming Pools in South-South Zone of South-Eastern Nigeria Using Microbiological and Physicochemical Indices. Southeast Asian Journal of Tropical Medicine and Public Health, 35, 488-493.

[9] CDC (2000) Pseudo Monastery Dermatitis/Folliculitis Associated with Pools and Hot Tubes—Colorado and Marine, 1999-2000. MMWR, 49, 1087-1091.

[10] Wade, T.J., Pai, N., Eisenberg, J.N.S. and Colford, J.M. (2003) Do U.S. EPA Water Quality Guidelines Recreational Waters Prevent Gastrointestinal Illness? A Systematic Review and Meta-Analysis. Environmental Health Perspective, 111, 1102-1109. http://dx.doi.org/10.1289/ehp.6241

[11] Kiyohara, N., Kibayakawa, Y.L., Lyman, H. and Osafune, I. (2010) Identification of Bacterial Flora in the Water of Swimming Pools throughout the Year. Japan Journal of Physical Education Health and Sports Sciences, 51, 1-9. http://dx.doi.org/10.5432/jjpehss.51.1

[12] Lagerkvist, B.J., Bernard, A.B., Bergstrom, E.F., Holmstrom, K. and Karp, K.G. (2004) Pulmonary Epithelial Integrity in Children: Relationship to Ambient Ozone Exposure and Swimming Pool Attendance. Environmental Health Perspective, 112, 1768-1771. http://dx.doi.org/10.1289/ehp.7027 
[13] Alice, L.S. (1977) Principles of Microbiology. 5th Edition, CV Mosby, London, 661-710.

[14] Harrigan, M.G. and McCane, M.E. (1976) Laboratory Methods in Food and Dairy Microbiology. Academic Press, London.

[15] Oxiod (1985) Oxoid Manual of Dehydrated Culture Media, Ingredients and Other Laboratory Services. Oxoid, Basingstoke.

[16] Cowan and Steel (1985) Manual for the Identification of Bacteria. Cambridge University Press, Cambridge.

[17] Holt, J.G., Krieg, N.R., Seath, P.H.A., Satley, J.T. and Williams, S.T. (1994) Bergey’s Manual of Determinative Bacteriology. 9th Edition, Williams and Wilkins, Baltimore, 804.

[18] Chrissanthy, P., Vangelis, E., Hercules, S., Panagiota, G., Giannakppoulos, X., Catherine, D., George, F., Helen, G., Panagiotis, K. and Stamatina, L. (2008) Microbiological Quality of Indoor and Outdoor Swimming Pools in Greece: Investigation of Antibiotic Resistance of the Bacterial Isolates. International Journal of Hygiene and Environmental Health, 211, 385-397. http://dx.doi.org/10.1016/j.ijheh.2007.06.007

[19] George, O., Simon, K.S., Emmanuel, L. and Emmanuel, T. (2014) Bacteriological Quality Assessment of Swimming Pools in Osu-Labadi Area, Accra. Journal of Natural Science Research, 4, 126-129.

[20] Sule, I.O., Agbabiaka, T.O., Saliu, B.K. and Oyerinde, E.O. (2010) Physicochemical and Bacteriological Assessment of Some Swimming Pools within Ilorin Metropolis, Kwara, Nigeria. Best Journal, 7, 108-112.

[21] Shittu, O.B., Olaitan, J.O. and Amusa, T.S. (2008) Physicochemical and Bacteriological Analyses of Water Used for Drinking and Swimming Purposes in Abeokuta, Nigeria. African Journal of Biomedical Research, 11, 285-290.

[22] Prescott, L.M., Harley, J.P. and Klein, O.A. (2002) Human Disease Caused by Bacteria. In: Prescott, L.M., Harley, J.P. and Klein, O.A., Eds., Microbiology, 5th Edition, McGraw-Hill Publisher, New York, 732-735.

[23] Sumerville, D.A. (1969) The Normal Flora of the Skin in Different Age Group. British Journal of Dermatology, 81, 248-258. http://dx.doi.org/10.1111/j.1365-2133.1969.tb13976.x

[24] Ramzi, M.H. and John, M.E. (2007) What to Do with Coagulate-Negative Staphylococci. The Canadian Journal of CME, 19-20.

[25] Fiorillo, L., Zucker, M., Sawyer, D. and Lin, A.N. (2001) The Pseudomonas Hot-Foot Syndrome. The New England Journal of Medicine, 345, 335-338. http://dx.doi.org/10.1056/NEJM200108023450504

[26] CDC (2004) An Outbreak of Norovirus Gastroenteritis at a Swimming Club_Vermont, 2004. Morbidity and Mortality Weekly Report, 53, 793-795.

[27] CDC (2004) Aseptic Meningitis Outbreak Associated with Echovirus 9 among Recreational Vehicle Campers-Connecticus, 2003. Morbidity and Mortality Weekly Report, 53, 710-713.

[28] Barben, T., Hafen, G. and Schmid, J. (2005) Pseudomonas aeruginosa in Public Swimming Pools and Bathroom Water of Patients with Cystic Fibrosis. Journal of Cystic Fibrosis, 4, 227-231. http://dx.doi.org/10.1016/j.jcf.2005.06.003

[29] WHO (2003) Guidelines for Safe Recreational Water Environments, Vol. 1, Coastal and Fresh Waters. WHO, Geneva.

[30] WHO (2004) Guidelines for Drinking Water Quality, Volume 1: Recommendations. 3rd Edition, WHO, Geneva. 